\title{
Article \\ The Effect of the Double Reasoned Maturation (DMR) Method on the Chemical Composition of the Juice and Wine of the Bianca Grape Cultivar
}

\author{
Diána Ágnes Nyitrainé Sárdy ${ }^{1}$, Erzsébet Krisztina Németh ${ }^{1, *}$, Réka Matolcsi ${ }^{1}$, Anna Szabó ${ }^{2}$ \\ and Zsuzsanna Varga ${ }^{1}$ \\ 1 Institute of Viticulture and Oenology, Hungarian University of Agriculture and Life Sciences, \\ Villányi Str 29-43, H-1118 Budapest, Hungary; nyitraine.sardy.diana.agnes@uni-mate.hu (D.Á.N.S.); \\ matolcsi.reka@phd.uni-mate.hu (R.M.); varga.zsuzsanna@uni-mate.hu (Z.V.) \\ 2 Institute of Horticultural Science, Hungarian University of Agriculture and Life Sciences, Villányi Str 29-43, \\ H-1118 Budapest, Hungary; szabo.anna@uni-mate.hu \\ * Correspondence: nemeth.erzsebet.krisztina@uni-mate.hu; Tel.: +36-7650-1430; Fax: +36-7650-1431
}

check for

updates

Citation: Nyitrainé Sárdy, D.Á.;

Németh, E.K.; Matolcsi, R.; Szabó, A.; Varga, Z. The Effect of the Double Reasoned Maturation (DMR) Method on the Chemical Composition of the Juice and Wine of the Bianca Grape Cultivar. Horticulturae 2022, 8, 97. https://doi.org/10.3390/ horticulturae 8020097

Academic Editor: Paolo Sabbatini

Received: 28 November 2021

Accepted: 18 January 2022

Published: 21 January 2022

Publisher's Note: MDPI stays neutral with regard to jurisdictional claims in published maps and institutional affiliations.

Copyright: (C) 2022 by the authors. Licensee MDPI, Basel, Switzerland. This article is an open access article distributed under the terms and conditions of the Creative Commons Attribution (CC BY) license (https:// creativecommons.org/licenses/by/ $4.0 /)$.

\begin{abstract}
This paper aims to detect the effects of DMR (double reasoned maturation) method, and if it is able to increase the quality of Hungary's most distributed white wine variety, Bianca. The resistant interspecific hybrid Bianca cultivar can accumulate high sugar content during ripening, but it is prone to drastic acid loss, which can lead to deficient microbiological stability of wines. The DMR method is suitable for achieving fruit with better sugar/acid ratio due to the shrinking of the berries. The DMR treatment was found to be a possible tool for avoiding rapid acid loss in Bianca juices. Early cutting of one-year-old wood and early harvest were found to be the ideal combination for increasing quality.
\end{abstract}

Keywords: color intensity; harvest time; Kunság wine region; polyphenols; resistant variety; shrinking time

\section{Introduction}

The efficiency of grape production depends on the area suitability, as well as the adapting capacity of the cultivar. The Kunság wine region is the largest grape producing area in proportion to its total size, where a wide assortment of grape cultivars can be found. The area can be characterized by extreme climatic conditions, namely the frequency of winter frosts and summer droughts. Regarding the stability of production, it is important to choose frost tolerant, high yielding cultivars with low manual labor requirements. This is the only way of cost-efficient cultivation. That is the reason for planting more resistant/tolerant cultivars in the Alföld (Great Hungarian Plain) region from 2000. A good example of that trend is the Aletta cultivar, whose total area in the Kunság wine region increased from 0 to 1055 hectares between 2002 and 2012, or the Bianca cultivar, whose total area increased from 615 to 3748 hectares [1]. Currently, the total area of Bianca is over 5000 hectares (25-30\% of the total area of the wine region), which shows the significance of the cultivar.

There is less experience in DMR (double maturation raisonnée or double reasoned maturation) than in common canopy management techniques. DMR is a special plant care method, which can be used for influencing the quality and the yield of the wine. This technique was first mentioned by Cargnello et al. [2,3], then Carbonneau and Murisier [4] introduced it in raisin grape production. In case of DMR, part of the one-year-old wood that bears shoots with clusters is cut off the vine-stock, and left on the trellis system until harvest. The treatment should be initiated one to two weeks prior to harvest, by leaving the cut parts on the wine-stock. Even though water circulation comes to a stop, the berries continue to evaporate and start to shrink, thus the cluster weight decreases [5-10]. 
According to Zanathy [8], DMR is suitable for cultivars with good sugar accumulation. He found that the advantages of this method are the increased sugar degree of the must, the elevated concentration of aromatic compounds and the increased titratable acidity [9]. This elevated sugar content can make the fruit suitable for producing wines with residual sugar content. Győrffyné Jahnke et al. [10] noted, though, that the rate of grey rot had not reduced with the treatment.

DMR causes a stress in the plant, which triggers a defense mechanism, and leads to the increased synthesis of secondary metabolites [11]. In their experiments Rescic et al. [12] found elevated levels of phenolic compounds, which led to the conclusion that DMR influenced and modified the composition of the grape and wine, especially the phenolic profile. Due to the stress the treatment causes to the plant, Győrffyné Jahnke et al. [13] and Gál et al. [14] recommend executing second year DMR in full maturity.

According to microvinifical experiments a higher extract, alcohol, titratable acidity, and polyphenol content can be measured in the test wines $[2,6,7]$.

The Bianca grape cultivar, which is an interspecific hybrid, is winter hardy, resistant to fungal diseases (powdery and downy mildew, botrytis), and high yielding, but susceptible to drought and bud load. Its growing season is relatively short, it ripens early. Similar to other resistant hybrids, it is generally high yielding, but cold, rainy weather has a negative effect on the flower set. The sugar content at ripening is high, but non-optimal harvest time could lead to a rapid acid loss [15]. In spite of being in cultivation for 25-30 years, there is still a lot to learn about the Bianca cultivar, as it behaves unpredictably under extreme climatic conditions, which are rather frequent in the Kunság wine region. Further studies need to focus on finding the optimal harvest time, and the effect of certain canopy management techniques on the yield and the quality.

This is why a three-year long experiment was designed to study the effect of the DMR method on the Bianca cultivar. The main focus of our study was to moderate the vintage year effect, to preserve the acidity, and improve chemical composition of the fruit. Our further goal was to try to achieve the best combination of cutting and harvest times in case of DMR method. We have also examined the effects of the treatment on some finer parameters, such as catechin, total polyphenol content of the wine.

\section{Materials and Methods}

\subsection{Place and Time of the Experiments}

The experiment was carried out in the Kecskemét Research Station of the Institute of Viticulture and Oenology, Hungarian University of Agriculture and Life Sciences, in the Kunság wine region (Figure 1). The location has warm and dry continental climate. Yearly sunshine is $2030-2050 \mathrm{~h}$. The absolute yearly maximum temperature is generally $34.2-34.5^{\circ} \mathrm{C}$, and the yearly average temperature is $11.2^{\circ} \mathrm{C}$ (according to the data from 1990-2020). Average temperature during vegetation is $17.2^{\circ} \mathrm{C}$. The yearly amount of rainfall is $450-550 \mathrm{~mm}$.

The soil type of the plantation is limic sand, shifting sand on yellow soil bedrock.

The plantation was established in 2006, with spacing of $2.8 \mathrm{~m}$ by $0.9 \mathrm{~m}$. Rootstock variety is Berlandieri X Riparia TK 5BB. The training system is Guyot-training.

Experiments were carried out in three years, in 2015, 2016, and 2017. All three years were warmer than average, with the occurrence of extremely hot days (Table 1).

Table 1. Local meteorological values of the years of experiments.

\begin{tabular}{cccccc}
\hline Year & $\begin{array}{c}\text { Yearly Average } \\
\text { Temperature }\left({ }^{\circ} \mathbf{C}\right)\end{array}$ & $\begin{array}{c}\text { Average Temperature } \\
\text { during Vegetation }\left({ }^{\circ} \mathbf{C}\right)\end{array}$ & $\begin{array}{c}\text { Absolute Maximum } \\
\text { Temperature }\left({ }^{\circ} \mathbf{C}\right)\end{array}$ & $\begin{array}{c}\text { Amount of Rainfall } \\
\text { during Vegetation }(\mathbf{m m})\end{array}$ & $\begin{array}{c}\text { Yearly Amount } \\
\text { of Rainfall }(\mathbf{m m})\end{array}$ \\
\hline 2015 & 12.23 & 18.9 & 37.18 & 338.1 & 599.1 \\
2016 & 11.6 & 18.6 & 38.52 & 328.2 & 634.9 \\
2017 & 11.53 & 18.71 & 40.12 & 328.5 & 601.3 \\
\hline
\end{tabular}




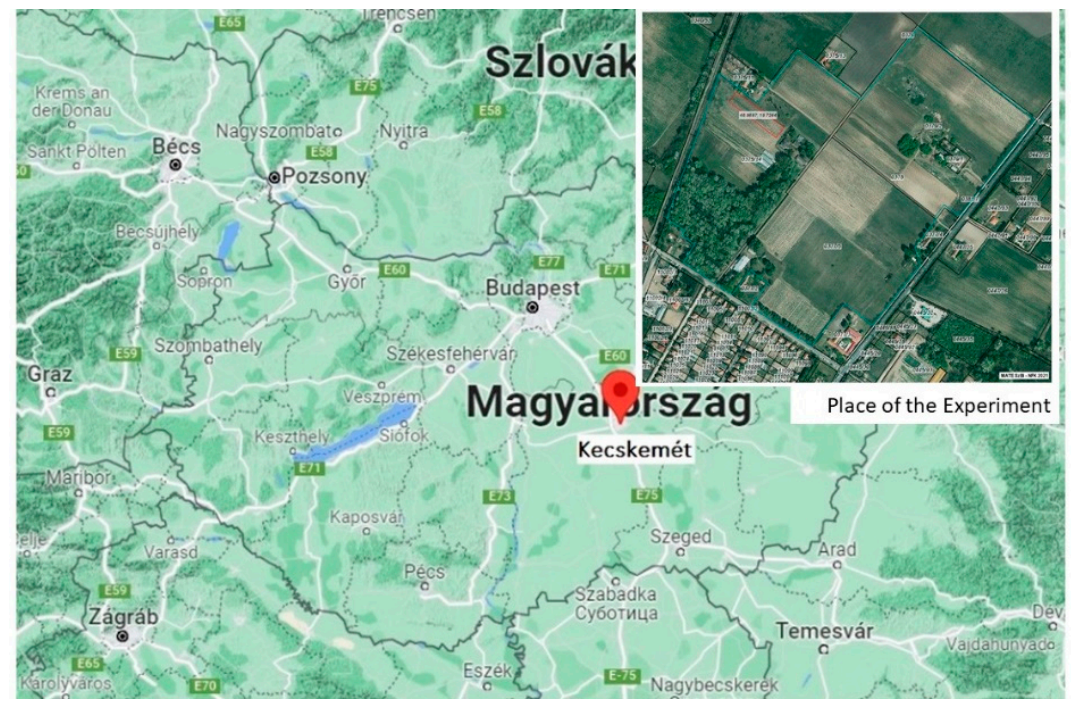

Figure 1. Place of the experiment.

\subsection{Description of the DMR Applied in the Experiment}

According to the preliminary principles all the cuttings of the one-year-old canes were made in the same weeks of August (33rd, 34th, and 35th weeks of the year), these treatment dates were combined with different harvest times.

In 2015, the DMR treatments were scheduled on different dates. The treatments are labelled after the "the week of cutting" $(33,34$ and 35). All three treatments were followed by harvests exactly one week later, respectively.

In 2016, the three DMR treatments were followed by harvest on one certain date (on the 36th week). Cutting was made on the same weeks as in $2015(33,34,35)$, resulting in one, two, or three weeks of shrinking time.

In 2017, the DMR application was scheduled for the same date in case of each plot (33rd week), but the harvest dates were different (exactly one, two and three weeks after cutting), according to the shrinking time. These are labelled as " $33+1$ ", " $33+2$ " and " $33+3$ ".

The first cutting is made at the beginning of the variety's ripening period for each treatment and the cutting and harvesting dates are adjusted accordingly.

In other words, the first cut at the time of the first harvest in 2015 followed by two more cuts (in this case, cuts two and three are made at a higher stage of ripening), with a delay of one week. All three cutting dates followed by harvest one week later, i.e., the second cutting date is also the harvest date of the first cutting in the treatment. The harvest of cut two coincides with cut three, while the harvest of cut three is the last one week after the cut.

In 2016, there were three different cutting dates with one harvest date, i.e., the canes were cut three consecutive times, one week apart from the beginning of ripening, but not harvested a week after the cutting. However, samples from each treatment were collected a week after the third cutting. In this case, the berries from the first cut had three weeks, from the second cut had two weeks, and from the third cut had only one week to wither, respectively. The primary objective here was to see what changes occur during the withering period or if there is a change in quality of the final product. The pruning dates were at different maturity levels and may reflect variations in weather.

In 2017, there was one cutting date with different harvest dates, that is, one pruning date at the beginning of ripening followed by harvest one, two or three weeks later, i.e., we set sugar and acid formation at one ripening stage, tried to influence the degree of withering with the harvest dates, and assumed that three different withering and ripening stages for intact berries would result in a quality difference. 
The cutting was done in the following way: the last two buds of the 12 budded 1-year-old canes were cut off together with the cluster/productive shoots. Unlike the traditional DMR method, we did not cut the entire stem, but only one sixth of the stem, thus avoiding the negative effects of cutting at the same point each year, and also allowing us to measure accurately the quantity of withered and intact berries, together with their quality parameters.

The experiment was carried out under field conditions in a production plantation. The experimental plots were arranged 50 plants/treatment per row in three replicates in a randomized arrangement, separated from each other. (Picture 1 small image of the area outlined in red on the map).

\subsection{Description of the Wine Making Technology Applied in the Experiment}

Control wines were created from intact clusters collected on the 36th week. After an immediate crushing and destemming, the wines were processed with the same technology. Must sulfating $\left(50 \mathrm{mg} / \mathrm{L} \mathrm{SO}_{2}\right.$ ) was followed by inoculation with a selected yeast strain (Uvaferm 228), and after the fermentation begun, the wines were treated with bentonite $(50 \mathrm{~g} / \mathrm{hL})$. Fermentation temperature was $14^{\circ} \mathrm{C}$. Before taking the samples only filtration was carried out. Bottling was not performed. Malolactic fermentation did not occur.

\subsection{The Laboratory Analysis of the Grape Juice and Wine Samples}

The berry weight measurements, and the laboratory analysis of the juice and wine samples were performed at the Hungarian University of Agriculture and Life Sciences Institute of Viticulture and Oenology, Department of Oenology.

The methods of the analyses in juice were the following: titratable acidity was measured by acid-base titration by E-COEI-1-DLTART, sugar content was determined with refractometer and converted to g/L through the OIV-MA-AS2-02:R 2012 method. In the case of wine, the following parameters were measured according to the listed methods: alcohol content was calculated through the OIV-MA-AS312-01A method. Color intensity was measured by spectrophotometry with absorbancy at 420 and $520 \mathrm{~nm}$, with a layer thickness of $1 \mathrm{~cm}$, according to the MSZ 14848-79 Hungarian standard. Total polyphenol content was determined by the Folin-Ciocalteau method [16], while leucoanthocyanidin content resulted from the application of hydrochloric acid butanol with Fe (II) -sulphate, after heating with a mixture of 40:60 hydrochloric acid butanol with Fe (II) -sulphate by spectrophotometry. The whole process was carried out via a modified Flanzy method [17]. Catechin level was measured in wine diluted with alcohol by reaction with sulfuric acid vanillin, values derived from spectrophotometry at $500 \mathrm{~nm}$ [18]. Free amino nitrogen content of the juice and wine (FAN) was measured according to the method developed by Nyitrainé Sárdy [19], while proline content was determined according to the method by Herbert et al. [20].

The statistical analysis was made by using IBM SPSS Statistics 23. ANOVA were applied in case of each analyzed parameter; every year was individually evaluated. Error bars on diagrams show the standard deviation of the values.

\subsection{Abbreviations in Diagrams}

Berry and juice values:

- 2015: $33 \mathrm{c}$-values at the cutting on the 33rd week, $33 \mathrm{~h}$-values at the harvest of the 33rd week treatment, $34 \mathrm{c}$-values at the cutting on the 34 th week, $34 \mathrm{~h}$-values at the harvest of the 34th week treatment, $35 \mathrm{c}$-values at the cutting on the 35th week, $35 \mathrm{~h}$-values at the harvest of the 35th week treatment;

- 2016: $33 \mathrm{c}$-values at the cutting on the 33rd week, $33 \mathrm{~h}$-values at the harvest of the 33rd week treatment, $34 \mathrm{c}$-values at the cutting on the 34 th week, $34 \mathrm{~h}$-values at the harvest of the 34th week treatment, $35 \mathrm{c}$-values at the cutting on the 35th week, $35 \mathrm{~h}$-values at the harvest of the 35th week treatment; 
- 2017: 33 c-values at the cutting on the 33rd week, $33+1$-values at the harvest after one week shrinking, $33+2$-values at the harvest after two weeks shrinking, $33+3$-values at the harvest after three weeks of shrinking.

Wine parameters:

- 2015: control wines, 33-wines made after cutting on the 33rd week, 34-wines made after cutting on the 34th week, 35-wines made after cutting on the 35th week;

- 2016: control wines, 33-wines made after cutting on the 33rd week, 34-wines made after cutting on the 34th week, 35-wines made after cutting on the 35th week;

- 2017: control wines, 33 + 1-wines made after one week shrinking, 33 + 2-wines made after two weeks of shrinking, $33+3$-wines made after three weeks of shrinking.

\section{Results and Discussions}

\subsection{Results of Berry and Juice Parameter Analysis}

Regarding the basic parameters of the three years of the experiments, no significant difference was found among the vintages, thus it is not considered to be a factor in the present evaluation.

The berry weight measurements in the three vintages are presented on Figure 2. Our data showed that applying DMR treatments resulted in water loss, and consequently in weight loss. In 2015, the berry weight decreased by $30 \mathrm{~g}$ in average in the course of only one week. In 2016, the loss was more significant, supposedly due to the originally higher values, and the longer shrinking time. The loss in each treatment were more than $60 \mathrm{~g}$ (69.6 g, $64.4 \mathrm{~g}$, and $62.1 \mathrm{~g}$, respectively). In 2017 the total average loss was $52.2 \mathrm{~g}$, but there was no significant difference among the DMR vines. The measured data of the 100 berries confirmed the findings of Rolle et al. and others [5,6,8-10] that DMR method results in the reduction of berry weight due to the water loss.

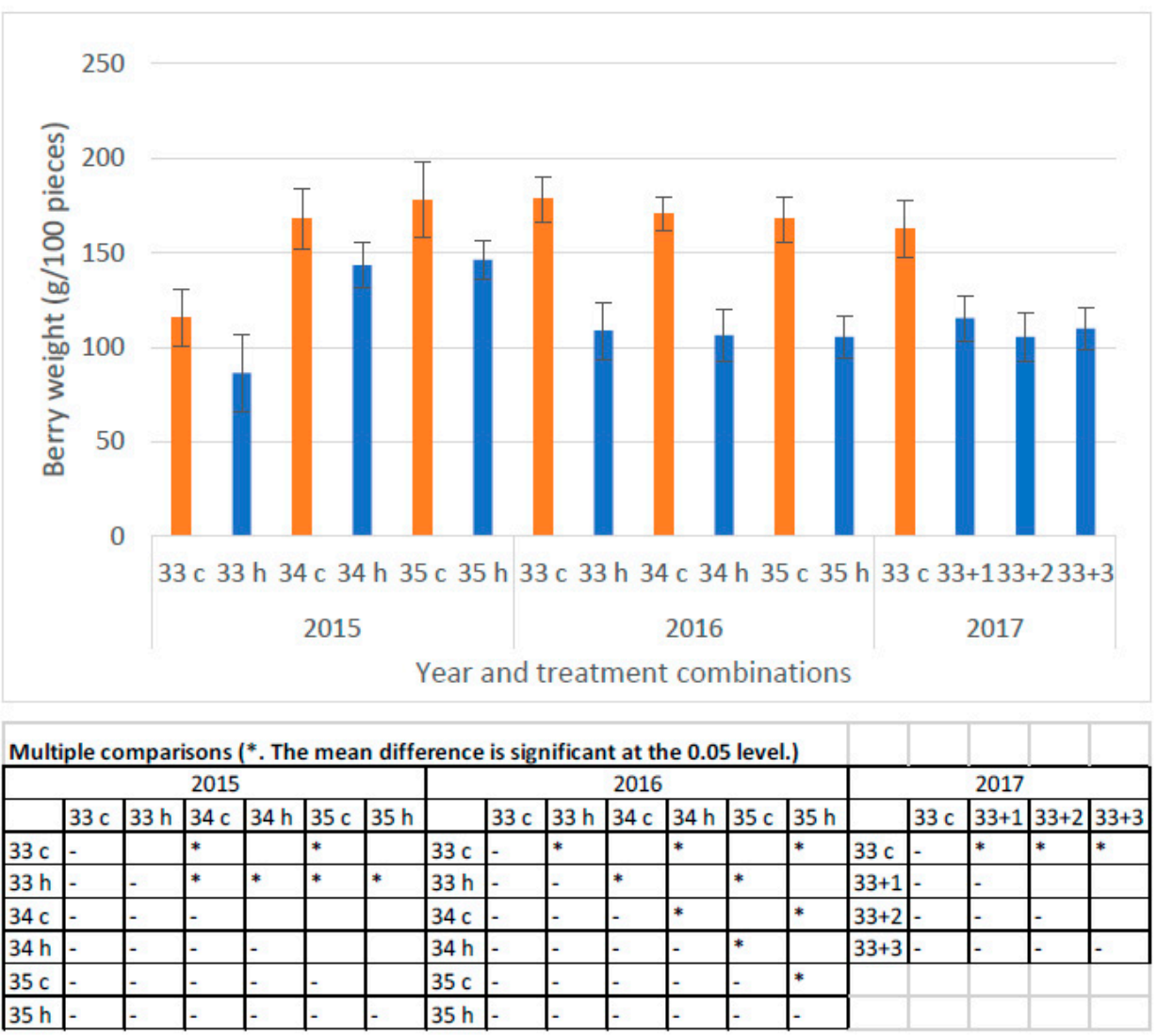

Figure 2. The effect of the different DMR treatments on the berry weight ( $\mathrm{g} / 100$ pieces). 
Significant differences could not be detected in the sugar content of the juice $(\mathrm{g} / \mathrm{L})$ in 2015 and 2016. A probable explanation of the stagnation in sugar content is that in both years, the average temperature dropped due to insistent precipitation during shrinking time. According to our data, only the DMR treatments of 2017 resulted in increased values parallel with the longer "shrinking time" (Figure 3). In 2017, DMR was applied on the same date (33rd week) on each of the three plots, the berries harvested first $(33+1)$ collected $57.7 \mathrm{~g}$ sugar from the cutting date, while one week later the samples of " $33+2$ " showed an average $66.2 \mathrm{~g}$ increase in sugar content. In the case of the third treatment $(33+3)$, a more moderated difference compared to " $33+2$ ", with $46.9 \mathrm{~g}$ higher values in average could be detected.

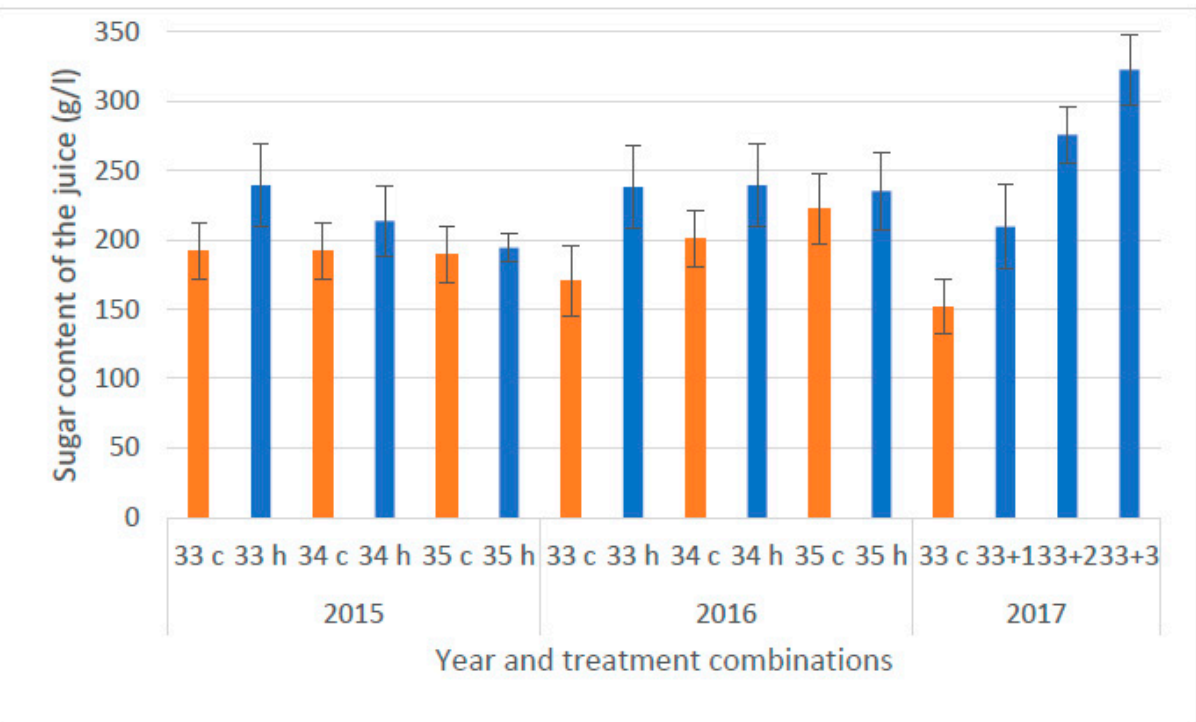

\begin{tabular}{|c|c|c|c|c|c|c|c|c|c|c|c|c|c|c|c|c|c|c|}
\hline Mult & ple co & mpar & isons & *. The & mea & $n$ diff & rence & is sig & ificar & t at th & 0.0 & 5 leve & & & & & & \\
\hline & & & 2015 & & & & & & & 2016 & & & & & & 2017 & & \\
\hline & $33 c$ & $33 \mathrm{~h}$ & $34 c$ & $34 \mathrm{~h}$ & $35 c$ & $35 \mathrm{~h}$ & & $33 c$ & $33 \mathrm{~h}$ & $34 c$ & $34 \mathrm{~h}$ & $35 c$ & $35 \mathrm{~h}$ & & $33 c$ & $33+1$ & $33+2$ & $33+3$ \\
\hline $33 c$ & - & & & & & & $33 c$ & - & & & & & & $33 c$ & - & & \begin{tabular}{|l|}
$*$ \\
\end{tabular} & * \\
\hline $33 \mathrm{~h}$ & - & - & & & & & $33 \mathrm{~h}$ & - & - & & & & & $33+1$ & - & - & & * \\
\hline $34 \mathrm{c}$ & - & - & - & & & & $34 \mathrm{c}$ & - & - & - & & & & $33+2$ & - & - & - & \\
\hline $34 \mathrm{~h}$ & - & - & - & - & & & $34 \mathrm{~h}$ & - & $E$ & - & - & & & $33+3$ & - & - & - & - \\
\hline $35 c$ & - & - & - & - & - & & $35 c$ & - & - & - & - & - & & & & & & \\
\hline $35 \mathrm{~h}$ & - & - & - & - & - & - & $35 \mathrm{~h}$ & - & - & - & - & - & - & & & & & \\
\hline
\end{tabular}

Figure 3. The effect of the different DMR treatments on the sugar content of the juice $(\mathrm{g} / \mathrm{L})$.

The increasing sugar content of the juice due to the DMR treatment in 2017 correlated with the concept published by Zanathy [8], but the 2015-2016 data did not support this finding. We could conclude that cutting at different dates, even combined with the same shrinking time, did not provide clear results. The basic values, namely the state of maturity at the time of cutting, could differ so severely that it overwrote the consequences of the different shrinking time. Thus, the effects were not provable statistically.

If simply the original aim of our study and the specialties of the cultivar were considered, the high sugar degree of the juice in the case of the " $33+3$ " samples were unfavorable, and the wine made from these shriveled berries might contain the typical unpleasant aroma and fragrance of the over-ripened Bianca grape.

Regarding the titratable acidity of the juice no significant difference among the vintages was found (Figure 4). Since the main focus in our investigations was to preserve as much titratable acidity as possible, we evaluated our findings from this point of view. In 2015, when DMR was applied on three different dates on the three plots, followed by harvests one week later, the first harvested samples had an acceptable $(6.6 \mathrm{~g} / \mathrm{L})$ titratable acidity, even though there was constant degradation of the titratable acidity in all three cases. In 2016, when DMR was applied with one week difference on the three plots, followed by 
harvest on the same day, negative changes were also measured in the titratable acidity due to the DMR treatments. In 2017, the acidity decreased more moderately parallel with the ripening. Even the longest shrinking time resulted in a favorable level of titratable acidity, thus drastic, disharmonic acid loss could not be avoided with the method.

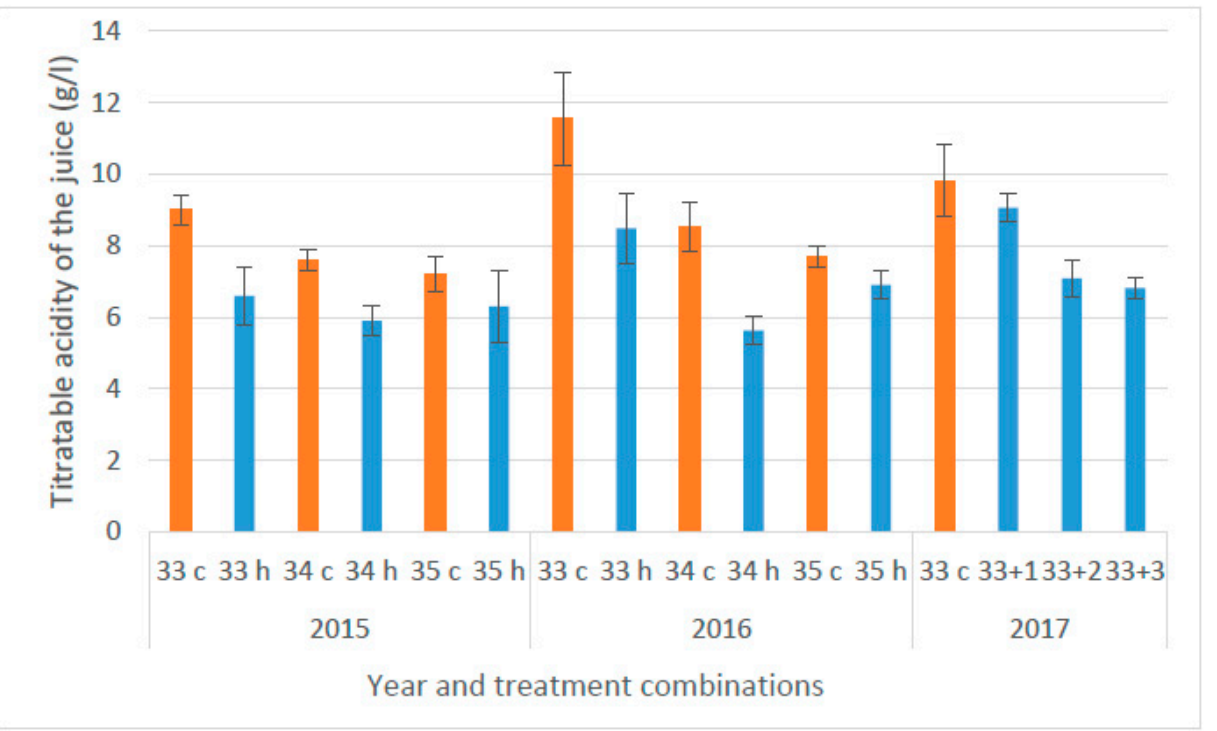

Multiple comparisons (*. The mean difference is significant at the 0.05 level.)
\begin{tabular}{|l|l|l|l|l|l|l|l|l|l|l|l|l|l|l|l|l|l|l|l|l|}
\hline \multicolumn{9}{|c|}{} \\
\hline & $33 \mathrm{c}$ & $33 \mathrm{~h}$ & $34 \mathrm{c}$ & $34 \mathrm{~h}$ & $35 \mathrm{c}$ & $35 \mathrm{~h}$ & & $33 \mathrm{c}$ & $33 \mathrm{~h}$ & $34 \mathrm{c}$ & $34 \mathrm{~h}$ & $35 \mathrm{c}$ & $35 \mathrm{~h}$ & & $33 \mathrm{c}$ & $33+1$ & $33+2$ & $33+3$ \\
\hline $33 \mathrm{c}$ & - & $*$ & & $*$ & & $*$ & $33 \mathrm{c}$ & - & $*$ & $*$ & $*$ & $*$ & $*$ & $33 \mathrm{c}$ & - & & $*$ & $*$ \\
\hline $33 \mathrm{~h}$ & - & - & & & & & $33 \mathrm{~h}$ & - & - & & $*$ & & & $33+1$ & - & - & & $*$ \\
\hline $34 \mathrm{c}$ & - & - & - & & & & $34 \mathrm{c}$ & - & - & - & & $*$ & & $33+2$ & - & - & - & \\
\hline $34 \mathrm{~h}$ & - & - & - & - & & & $34 \mathrm{~h}$ & - & - & - & - & $*$ & & $33+3$ & - & - & - & - \\
\hline $35 \mathrm{c}$ & - & - & - & - & - & & $35 \mathrm{c}$ & - & - & - & - & - & & & & & \\
\hline $35 \mathrm{~h}$ & - & - & - & - & - & - & $35 \mathrm{~h}$ & - & - & - & - & - & - & & & & \\
\hline
\end{tabular}

Figure 4. The effect of the different DMR treatments on the titratable acid content of the juice $(\mathrm{g} / \mathrm{L})$.

In each year of the experiment, the titratable acidity decreased between the DMR application and the harvest, which contradicts the data published by Corso et al. [6], who referred to elevated acid values due to the treatment.

Generally, we can claim all these low values in titratable acidity are unfavorable for the cultivar. Considering wine technology, as a raw material, the DMR case of the " $33+1$ " of 2017 was proved to have the best effect, in other words "minimal loss in titratable acidity", which means that in case of the Bianca cultivar, early cutting and short shrinking time is suggested.

We determined FAN values in the juices. Values measured in the samples varied between 221 and $359 \mathrm{mg} / \mathrm{L}$, and the average FAN was around $276 \mathrm{mg} / \mathrm{L}$. We can state that all of the later harvested samples, even if treated earlier, resulted in higher FAN values. Therefore, we could note that time has an influence on FAN values, but the effect of DMR treatment is not proved in this experiment.

\subsection{Results on Wine Parameters}

Control wines were produced from intact clusters collected on the 36th week. Due to this later harvest time, all the control wines provided high alcohol content (Figure 5), each sample reached an unfavorably high average (above $14 v / v \%$ ). The harvest time for control samples represents an overripened state of the berries according to the alcohol content. Similarly high values could be detected in the latest harvest of 2015 (35) and in the latest treatment of 2016 (35). Earlier harvests and earlier treatment (33 and 34 in 2015 and 2016, respectively), besides earlier harvest in $2017(33+1$ and $33+2)$ resulted in more favorable values (around $12 v / v \%$ ). However, we could not find any significant difference 
between the first two treatments in the years of experiments despite the later harvest or longer shrinking time. Therefore, we can conclude that the DMR treatment did not prove to have a clear and consistent effect on the alcohol levels of the samples. Regarding this parameter the time of harvest was the major deciding factor in our investigations.

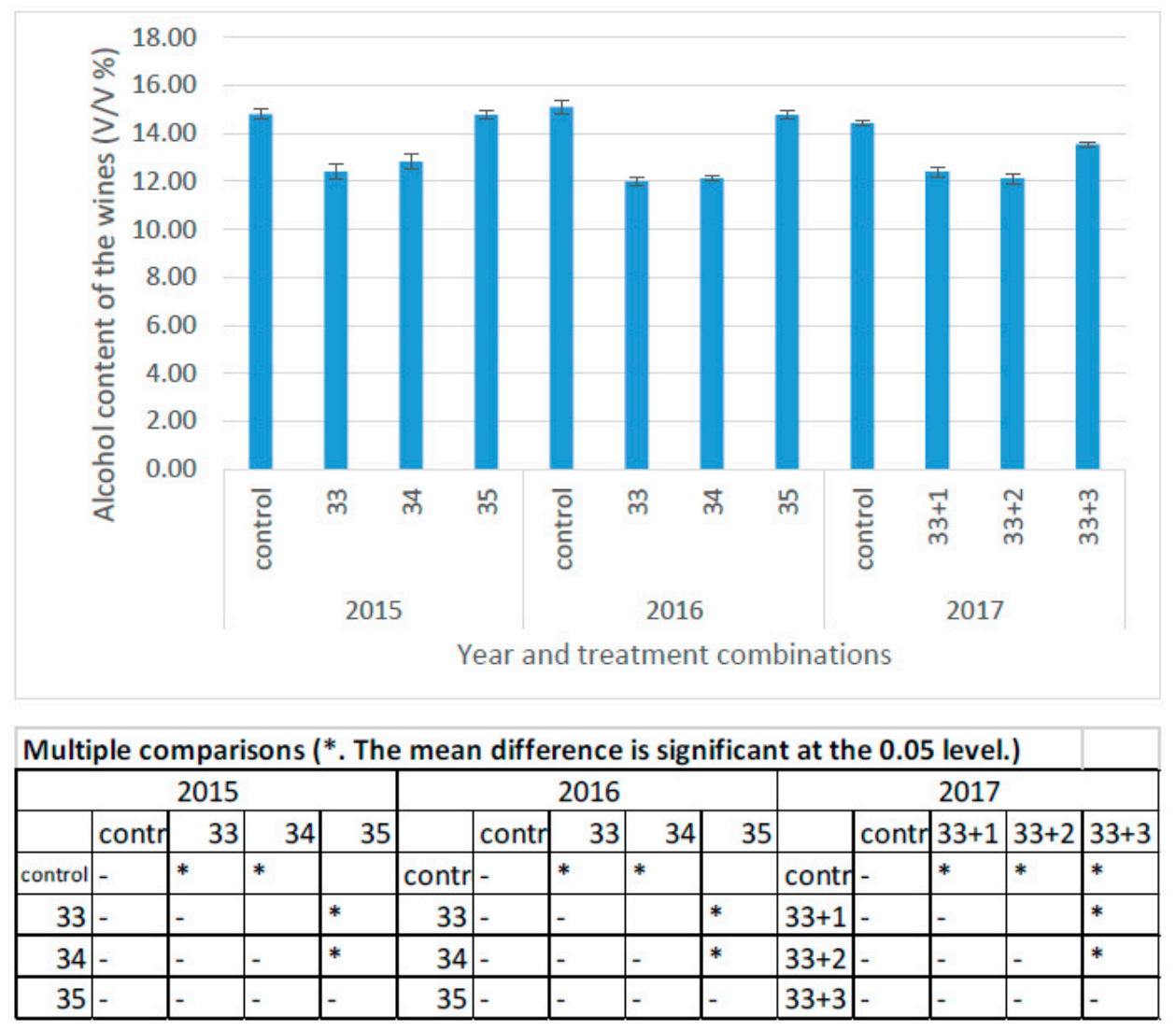

Figure 5. Alcohol content of the wines in 2015-2017 (v/v\%).

Not only the sugar content and titratable acidity of the juice, but the alcohol levels of the sample wines proved that early treatment and early harvest are favorable in case of the Bianca cultivar.

If we evaluate the titratable acidity of the wines (Figure 6), we can state that the samples of DMR treatment resulted in higher titratable acidity in 2015 and 2016. Control values were significantly lower in both years, while the different treatments were statistically equal. Averages in 2017 were similar, as all the values were under $6 \mathrm{~g} / \mathrm{L}$. Due to the weather of this vintage DMR treatment did not have a significant effect regarding the titratable acidity of the wines.

The color intensity (Figure 7) was determined in the control and DMR wines, and significant differences among certain samples were found. In 2015, the average of the late treatment and the control harvest was equal, while in the 33 and 34 wines, the color intensity was lower. In 2016, the control wines and the longest shrinking time provided the highest intensity. In 2017, treatments did not prove to have a consistent effect on the color intensity of the wines, and all values were statistically equal in this year. 


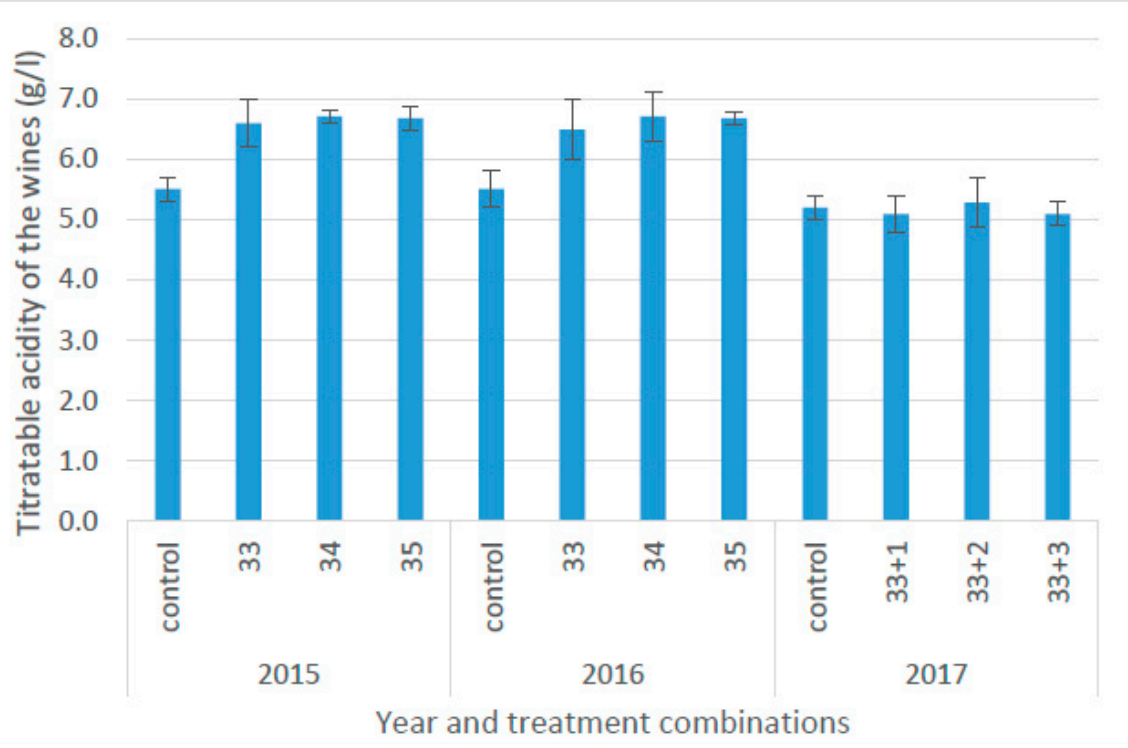

\begin{tabular}{|c|c|c|c|c|c|c|c|c|c|c|c|c|c|c|}
\hline \multicolumn{5}{|c|}{2015} & \multicolumn{5}{|c|}{2016} & \multicolumn{5}{|c|}{2017} \\
\hline & contr & 33 & 34 & 35 & & contr & 33 & 34 & 35 & & contr & $33+1$ & $33+2$ & $33+3$ \\
\hline control & - & * & * & $*$ & contr & - & * & * & * & contr & - & & & \\
\hline 33 & - & - & & & 33 & - & - & & & $33+1$ & - & - & & \\
\hline 34 & - & - & - & & 34 & - & - & - & & $33+2$ & - & - & - & \\
\hline 35 & - & - & - & - & 35 & - & - & - & - & $33+3$ & - & - & - & - \\
\hline
\end{tabular}

Figure 6. Titratable acidity of the wines in 2015-2017 (g/L).

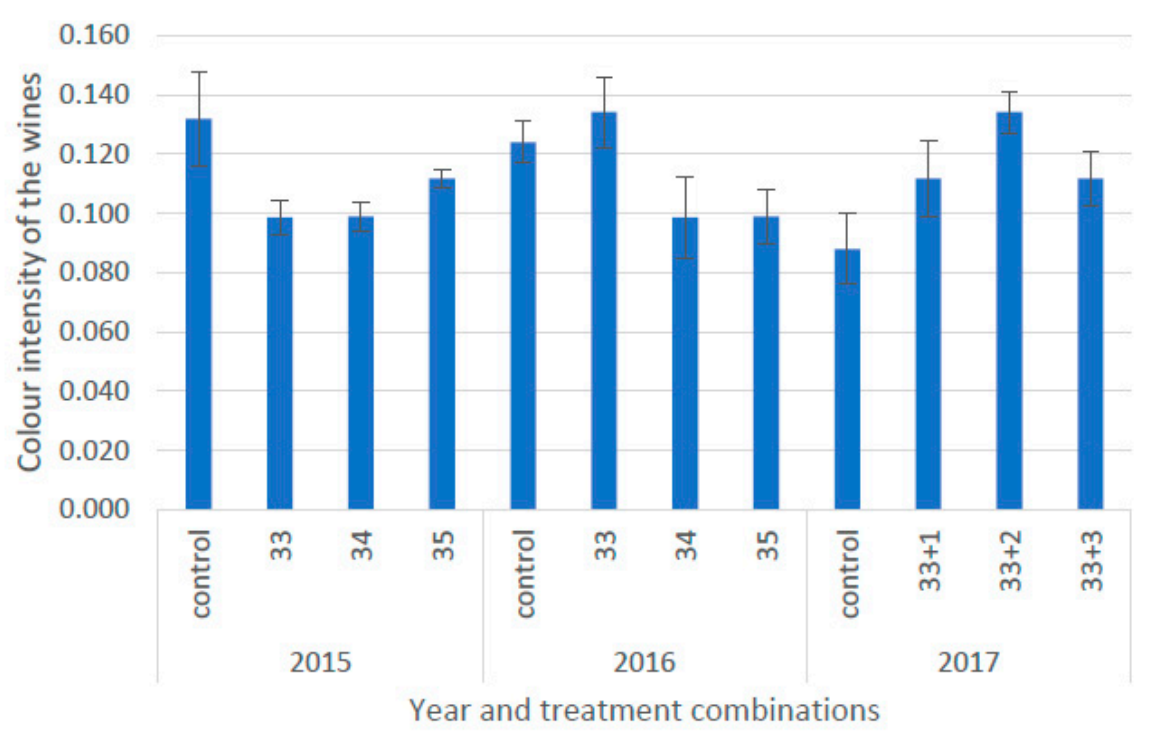

Multiple comparisons ( $*$. The mean difference is significant at the 0.05 level.)

\begin{tabular}{|r|l|l|l|r|r|r|r|r|r|r|r|r|r|r|}
\hline \multicolumn{9}{|c|}{2015} & \multicolumn{9}{|c|}{2016} & \multicolumn{5}{|c|}{2017} \\
\hline & contr & 33 & 34 & 35 & & contr & 33 & 34 & 35 & & contr & $33+1$ & $33+2$ & $33+3$ \\
\hline control & - & $*$ & $*$ & & contr & - & & & & contr & - & & $*$ & \\
\hline 33 & - & - & & & 33 & - & - & $*$ & $*$ & $33+1$ & - & - & & \\
\hline 34 & - & - & - & & 34 & - & - & - & & $33+2$ & - & - & - & \\
\hline 35 & - & - & - & - & 35 & - & - & - & - & $33+3$ & - & - & - & - \\
\hline
\end{tabular}

Figure 7. Color intensity of the wines on $420 \mathrm{~nm}$ in 2015-2017. 
The tendency of color change did not prove a conclusive result in any case. These results partly confirmed the findings of Cargnello et al. [2], who reported elevated color intensity in wines due to DMR treatments. Since Bianca is a white wine cultivar, in regard to color intensity, early cutting and early harvest is also suggested.

In this experiment total polyphenol levels were measured between 242 and $312 \mathrm{mg} / \mathrm{L}$ (Figure 8). Comparing the total polyphenol content of the sample wines, clear and consistent effects due to the DMR treatment were not found; even the time of harvest did not prove to be a significant factor in the values.

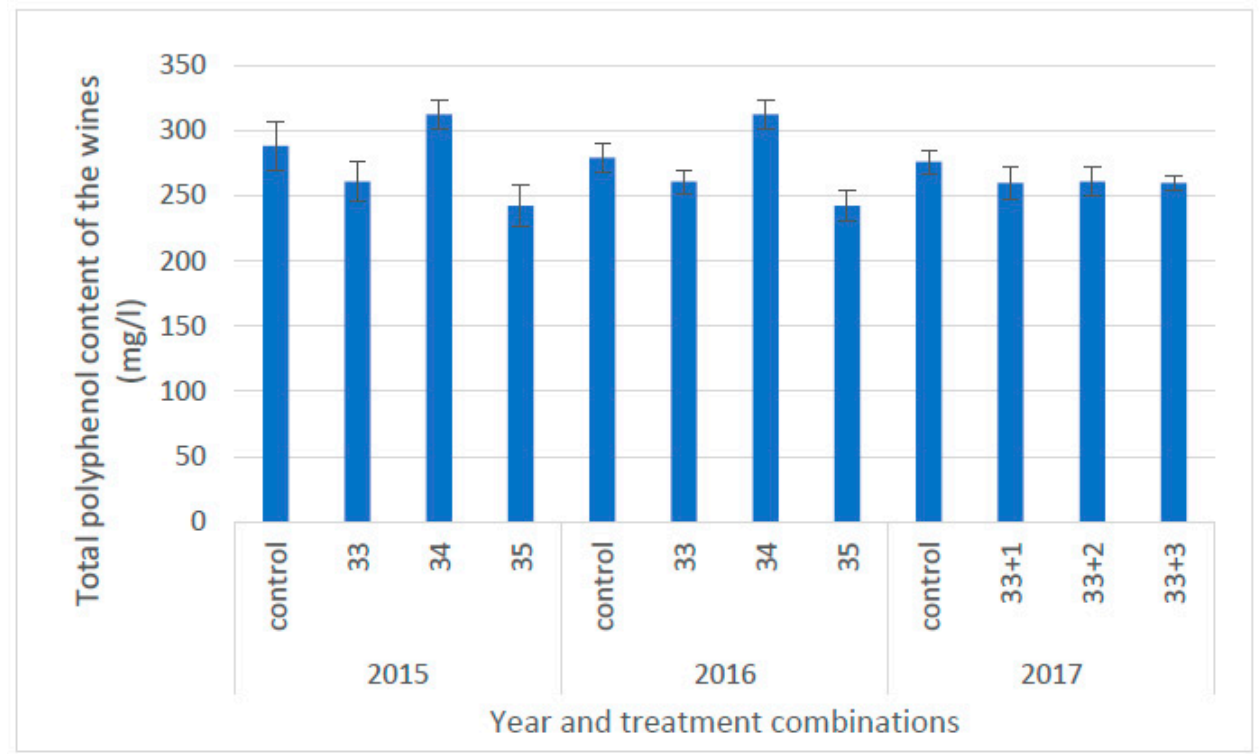

\begin{tabular}{|c|c|c|c|c|c|c|c|c|c|c|c|c|c|c|}
\hline \multicolumn{5}{|c|}{2015} & \multicolumn{5}{|c|}{2016} & \multicolumn{5}{|c|}{2017} \\
\hline & contr & 33 & 34 & 35 & & contr & 33 & 34 & 35 & & contr & $33+1$ & $33+2$ & $33+3$ \\
\hline control & - & & & * & contr & - & & & * & contr & - & & & \\
\hline 33 & - & - & $*$ & & 33 & - & - & * & & $33+1$ & - & - & & \\
\hline 34 & - & - & - & $*$ & 34 & - & - & - & * & $33+2$ & - & - & - & \\
\hline 35 & - & - & - & - & 35 & - & - & - & - & $33+3$ & - & - & - & - \\
\hline
\end{tabular}

Figure 8. Total polyphenol content of the wines in 2015-2017 (mg/L).

Our data could not confirm the results of Rescic et al. [12], who found that due to DMR, more polyphenols can get into the must. Neither were the results of Haug et al. [7] affirmed, who reported similar results in their studies on the Garanoir cultivar. The reason for lower polyphenol concentrations in samples from later harvests may be due to oxidation.

In case of the catechin content of the wines (Figure 9), we found that the values of the juice samples generally increased by almost each later harvest date. In 2015, catechin levels of the control wines and the later treatment were higher, while early cuttings and early harvest values were equally lower. In 2016, early cuttings $(33,34)$ resulted in lower catechin content. In 2017, for the most part, the average of the shortest shrinking time $(33+1)$ was significantly lower. 


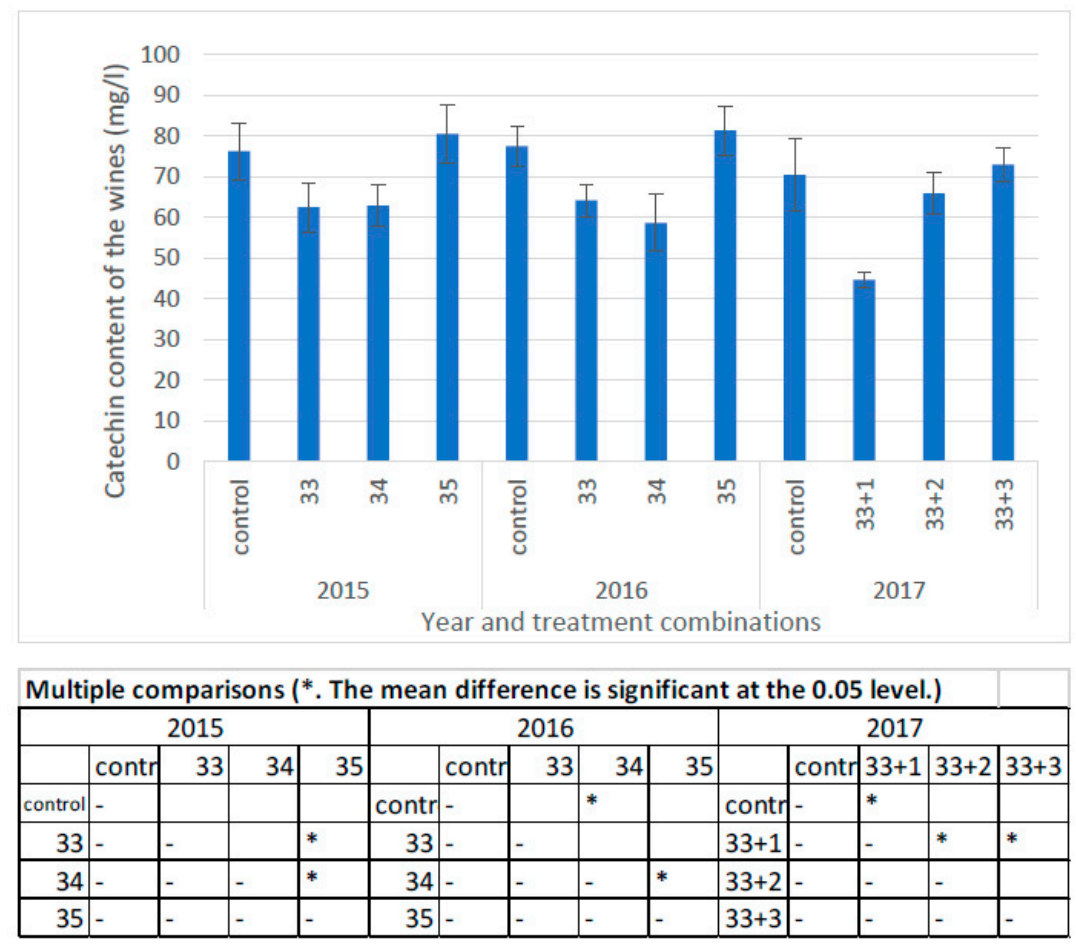

Figure 9. Catechin content of the wines in 2015-2017 (mg/L).

According to our data, we can state that earlier cutting and shorter shrinking time resulted in lower catechin values. These samples were characterized by even lower values than the control wines.

Any significant differences in the leucoanthocyanidin levels were not found. Astringent taste is determined by the polymerization degree. Previous research has proven that this value can be increased by $1.7 \mathrm{mg} / \mathrm{L}$ due to DMR [21]. Our data could not confirm these results.

Due to the effect of the yeast and the process of fining, the free amino nitrogen contents (FAN) of the wines are lower than that of the musts. The values measured in the wine samples varied between 93 and $209 \mathrm{mg} / \mathrm{L}$, and the average FAN was around $131 \mathrm{mg} / \mathrm{L}$. Since we applied the same method and yeast to prepare the samples, similar nitrogen levels could be expected. Any occurring differences in the FAN values presumably derived from the differences of the original samples, which might have been affected by DMR application. However, no significant differences in any cutting-harvest combinations were found, thus, DMR treatments proved to have no clear and consistent effect on FAN values.

We had similar conclusion in case of proline content, no significant differences among the values were found here either. Hence DMR application and different harvest times did not have an effect on the proline content of the wines.

\section{Conclusions}

DMR treatment did not have clear effect on the sugar content of the juice. Certain cutting-harvest combinations (33 +1 in 2017) resulted in unfavorably high sugar levels. The major aim in our investigations was to find out if DMR treatment is suitable to preserve more titratable acidity compared to the regular ripening. However, in each year of the experiment the titratable acidity decreased between the DMR application and the harvest. From the aspect of wine technology, the combination with minimal loss in titratable acidity (" $33+1$ " of 2017) can be suggested, namely, in the case of Bianca, early cutting and short shrinking time is the best combination.

In the latest harvest of 2015 and in the latest treatment of 2016, besides control samples, alcohol content reached unfavorably high levels (above $14 v / v \%$ ), while earlier cuttings and earlier harvest resulted in a more ideal alcohol content (around $12 v / v \%$ ). Our results 
confirmed that the date of harvest has the stronger effect on these values, DMR treatment influenced this parameter less. Considering the other effects of DMR treatment, alcohol levels also confirmed that earlier cutting and/or earlier harvest is the preferable method. DMR treatment did not have a consistent effect on the color intensity of the wines. In the case of total polyphenol content, no significant differences were found. Catechin values were proved to be lower with early cutting and shorter shrinking time. No significant differences due to DMR treatment in leucoanthocyanidin levels, free amino nitrogen, and proline content were found.

Several values (sugar and titratable acidity of the juice, besides the alcohol levels of the wines) confirmed that early treatment and early harvest are favorable in case of the cultivar Bianca.

In further experiments in this topic, certain adjustments would be advised. For example, a higher rate of DMR application should be tested, and in the meantime a shorter shrinking period should be set in order to be able to find the optimal combination of the two treatments for achieving an optimal sugar-acid ratio.

Author Contributions: Conceptualization, methodology and resources, D.Á.N.S. and E.K.N.; formal analysis and investigation, R.M.; writing-original draft preparation, A.S.; writing-review and editing, Z.V. All authors have read and agreed to the published version of the manuscript.

Funding: This research was supported by the Ministry for Innovation and Technology within the framework of the Thematic Excellence Programme (TKP2020-NKA-16).

Institutional Review Board Statement: Not applicable.

Informed Consent Statement: Not applicable.

Data Availability Statement: Not applicable.

Conflicts of Interest: The authors declare no conflict of interest.

\section{References}

1. Gácsi, A.; Zanathy, G.; Lőrincz, A.; Keresztes, J.; Botos, E.P. Helyzetkép a Kunsági Borvidék Szőlőtermesztéséről. Borászati Füzetek Kut. 2013, 24, 19-24.

2. Cargnello, G.; Persuric, D. Premieres Recherches Sur La “Double Maturation Raisonnée” (D.M.R.) En Istrie (Croatie). In Proceedings of the Gesco 9, Budapest, Hungary, 21-23 August 1996; pp. 97-103.

3. Cargnello, G.; Garofolo, A.; Tiberi, D. Ultrieures Recherches Sur La Technique de La Double Maturation Raisonnée (D.M.R.) Sur Raisins et Vins Cesanese Del Piglio Doc Provenant de Zones et Systemes Du Conduite Differents. In Proceedings of the Gesco 9 , Budapest, Hungary, 21-23 August 1996; pp. 111-120.

4. Carbonneau, A.; Murisier, F. Passerillage Sur Souche: Une Technique Innovante de Raisonnement de La Maturation Au Service de La Viticulture Durable. Une Alternative à l'enrichissement En Sucres: Synthèse d'essais. In Bulletin de l'OIV; Office International de la Vigne et du Vin: Paris, France, 2009; pp. 17-31.

5. Rolle, L.; Torchio, F.; Giacosa, S.; Gerbi, V. Modifications of Mechanical Characteristics and Phenolic Composition in Berry Skins and Seeds of Mondeuse Winegrapes throughout the On-Vine Drying Process. J. Sci. Food Agric. 2009, 89, 1973-1980. [CrossRef]

6. Corso, M.; Ziliotto, F.; Rizzini, F.M.; Teo, G.; Cargnello, G.; Bonghi, C. Sensorial, Biochemical and Molecular Changes in Raboso Piave Grape Berries Applying “Double Maturation Raisonnée” and Late Harvest Techniques. Plant Sci. 2013, 208, 50-57. [CrossRef]

7. Haug, R.; Rösti, J.; Zufferey, V. Fruchtrutenschnitt Bei Garanoir. In Schweizer Zeitschrift Für Obst-Und Weinbau; Zurich University of Applied Sciences: Winterthur, Switzerland, 2012; Volume 15, pp. 4-7.

8. Zanathy, G. Mi Is Az a DMR? Agrofórum 2010, 21, 94-96.

9. Zufferey, V.; Ferretti, M.; Rigoni, R.; Murisier, F.; Rösti, J.; Dienes-Nagy, Á.; Belcher, S.; Koestel, C.; Verdenal, T.; Spring, J.-L. Verbesserung der Traubenqualität Durch Eintrocknen Mit Fruchtrutenschnitt: Versuche Mit Carminoir Im Tessin. Rev. Suisse Vitic. Arboric. Hortic. 2016, 48, 304-309.

10. Győrffyné Jahnke, G.; Májer, J.; Varga, P.; Németh, C.; Knolmajerné Szigeti, G.; Szőke, B.D.M.R. Módszer Alkalmazása "Juhfark”, “Szürkebarát" És "Pinot Noir" Szőlőfajtáknál. Kertgazdaság 2011, 43, 34-38.

11. Bonghi, C.; Rizzini, F.M.; Gambuti, A.; Moio, L.; Chkaiban, L.; Tonutti, P. Phenol Compound Metabolism and Gene Expression in the Skin of Wine Grape (Vitis Vinifera L.) Berries Subjected to Partial Postharvest Dehydration. Postharvest Biol. Technol. 2012, 67, 102-109. [CrossRef]

12. Reščič, J.; Mikulič-Petkovšek, M.; Rusjan, D. The Impact of Partial Dehydration on Grape and Wine Chemical Composition of White Grapevine (Vitis Vinifera L.) Varieties. Eur. J. Hortic. Sci. 2016, 81, 310-320. [CrossRef] 
13. Győrffyné Jahnke, G.; Bényei, F.; Kaptás, T.; Kozma, P.; Májer, J.A.D.M. R Módszer Felhasználási Lehetőségei. In Proceedings of the Lippay-Vas-Ormos Napok, Budapest, Hungary, 7-8 November 2007.

14. Gál, L.; Kaptás, T.; Szúcs, E. A Terméskorlátozás És a Szüreti Időpont Megválasztásának Hatása a Blauburger Fajta Borminőségére. In “Terméskorlátozás-Mítosz és Valóság” Címü Szakmai Nap; Egyetem Georgikon Mezőgazdaságtudományi Kar Kertészeti Tanszék: Keszthely, Hungary, 2007.

15. Bényei, F.; Lőrincz, A. Borszőlófajták, Csemegeszőlo-Fajták És Alanyok; Mezőgazda Kiadó: Budapest, Hungary, 2005.

16. Kállay, M.; Török, Z.; Korány, K. Investigation of the Antioxidant Effect of Hungarian White Wines and Tokaj Wine Specialities. Int. J. Hortic. Sci. 1999, 5, 22-26. [CrossRef]

17. Flanzy, M.; Aubert, S.; Marinos, M. New Technique for Determination of Leukoanthocyanidin Tannins. Applications. Ann. Technol. Agric. 1969, 18, 327-328.

18. Rebelein, H. Beitrag Zur Bestimmung Des Catechingehaltes in Wein. In Deutsche Lebensmittel Rundschau; Behr's Verlag: Hambrug, Germany, 1965; pp. 182-183.

19. Nyitrainé Sárdy, D. Különböző Bioélesztők Hatása Bianca Borok Kémiai Összetételére. Borászati Füzetek一Kutatás 2015, 26, 1-3.

20. Herbert, P.; Barros, P.; Ratola, N.; Alves, A. HPLC Determination of Amino Acids in Musts and Port Wine Using OPA/FMOC Derivatives. J. Food Sci. 2000, 65, 1130-1133. [CrossRef]

21. Mikulic-Petkovsek, M.; Jug, T.; Rescic, J.; Rusjan, D. Effects of Partial Dehydration Techniques on the Metabolite Composition in 'Refošk' Grape Berries and Wine. Turk. J. Agric. For. 2017, 41, 10-22. [CrossRef] 